\title{
Influence of pregnancy, oophorectomy and contraceptive steroids on gall bladder concentrating function and hepatic bile flow in the cat
}

\author{
G RÅDBERG AND J SVANVIK \\ From the Department of Surgery I, Sahlgrenska Sjukhuset, Göteborg, Sweden
}

SUMMARY Pregnancy and contraceptive steroids are associated with a raised incidence of cholesterol gall stone disease. In pregnancy there is an increase in the size of the gall bladder. Investigation of hepatobiliary function in man and mammals has not established if the enlarged gall bladder is simply dilated, or if the absorptive capacity of the mucosa has changed. In the present study the concentrating function of the gall bladder and bile secretion from the liver were studied in pregnant animals, oophorectomised animals and animals treated for three months with contraceptive steroids. The effects of intravenous administration of prolactin, progesterone and oestrogen were studied in oophorectomised animals. It was found that the net rate of water absorption in the gall bladder of pregnant animals was doubled, while oophorectomy and contraceptive steroids did not affect this variable. The volume outflow of bile was enhanced in pregnant animals and in animals treated with contraceptive steroids. Intravenous infusions of prolactin, oestrogen or progesterone were found not to influence gall bladder concentrating function, nor hepatic bile secretion in oophorectomised animals.

The prevalence of cholesterol gall stones in women is higher during the childbearing years compared with men. ${ }^{1}$ Pregnancy, ${ }^{2}$ oral contraceptives ${ }^{3}$ and oestrogen administration ${ }^{4}$ increase the risk of gall stones. The biochemical and physiological changes responsible for this are not fully known. An increased cholesterol saturation in the hepatic and gall bladder bile of pregnant women has been demonstrated..$^{5}$ A recent study has shown that the combination of etinyloestradiol and norgestrel but not etinyloestradiol alone will increase cholesterol saturation in gall bladder bile. ${ }^{6}$ The bile acid pool size as measured with isotope dilution techniques is found to be reduced in the pregnant baboon ${ }^{6}$ but is increased in early pregnancy in man. ${ }^{5}$ The bile acid pool size is reduced in response to contraceptive steroids. ${ }^{89}$ It is not known whether these changes in the bile acid metabolism primarily are induced by a changed liver function or an influence on the extrahepatic part of the enterohepatic circulation.

The two main functions of the gall bladder are motility and net absorption of water and electrolytes

Address for correspondence: Dr Joar Svanvik, Department of Surgery I, Sahlgrens' Hospital, S-413 45 Göteborg, Sweden.

Received for publication 18 March 1985 across the mucosa. It has recently been shown that the fasting volume of the gall bladder is increased and the emptying in response to a liquid meal is reduced in late pregnancy while contraceptive steroids do not affect gall bladder motility. ${ }^{10}$ The influence of pregnancy, contraceptive steroids, and oophorectomy on gall bladder concentrating function are not known. Early studies suggest that gall bladder concentrating function may be impaired during pregnancy and parturition. Riegel and coworkers $^{11}$ studied the composition of gall bladder bile in pregnant women at term and found changes consistent with impaired gall bladder concentrating function. Potter ${ }^{12}$ observed that the gall bladder in pregnant women undergoing caesarian section was distended, containing bile of a composition similar to hepatic bile. In a later study by Large and coworkers $^{13}$ in pregnant women the chemical composition of gall bladder bile did not indicate an impaired gall bladder concentrating function. Preliminary in vitro findings have shown an inhibition of water transport across the wall of gall bladders from female guinea pigs ${ }^{14}{ }^{15}$ by oestrogen and progesterone. The effects in vivo by pregnancy, contraceptive steroids and oophorectomy are not further known. 
Gall bladder function in several physiological and pathophysiological conditions has earlier been studied in the cat in our laboratory. In the present study, the gall bladder function and hepatic bile flow in pregnant, oophorectomised and oral contraceptive treated cats were compared with controls. The effects of infusion of female sex hormones on gall bladder concentrating function and hepatic bile secretion in anaesthetised cats were also studied.

\section{Methods}

ANIMALS

Experiments were carried out on 33 female cats (weight range $3 \cdot 5-5 \cdot 2 \mathrm{~kg}$ ). Gall bladder concentrating function and fasting bile flow were estimated in the anaesthetised animals in acute experiments.

\section{EXPERIMENTAL GROUPS}

(1) Controls $(n=6),(2)$ animals pregnant at term $(n=9)$, (3) animals oophorectomised two months before the experiments $(n=12),(4)$ animals treated for three months with peroral etinyloestradiol $(2.5$ $\mu \mathrm{g} / \mathrm{kg} /$ day $)$ and levonorgestrel $(12.5 \mu \mathrm{g} / \mathrm{kg} /$ day $(n=6)$.

\section{OOPHORECTOMY PROCEDURES}

Twelve female cats were anaesthetised with ketmine hydrochloride $\left(\mathrm{Ketalar}^{\mathrm{R}}\right.$ ) $30-50 \mu \mathrm{g} / \mathrm{kg} / \mathrm{bw}$. A lower midline laparotomy was done under sterile conditions and both ovaries and the major parts of the uterine tubes were removed. The midline incision was closed and the animals were studied after $10 \pm 7$ weeks.

\section{EXPERIMENTAL PROCEDURES}

The animals, deprived of food for 24 hours, after induction with Ketamine were anaesthetised intravenously with chloralose $(50-70 \mathrm{mg} / \mathrm{kg} \mathrm{bw})$. The experimental procedure was similar to that described by Svanvik and Jansson in $1977 .{ }^{16}$ To summarise: the gall bladder was cannulated in situ and continuously perfused with a buffer solution by a roller pump at a rate of $0.15 \mathrm{ml} / \mathrm{min}$. The perfusion system began and ended in two separate chambers on an electromagnetic balance, the total weight on which was continuously registered by an inkwriter. The hydrostatic pressure in the gall bladder was set at $7 \mathrm{~cm} \mathrm{H}_{2} \mathrm{O}$ by adjusting the height of the balance. A non-absorbable tracer, ${ }^{14} \mathrm{C}$-polyethylene glycol (PEG), was added to the perfusate. The net fluid transport was calculated from the perfusion rate and the change in concentration of the tracer during its passage through the gall bladder. With no change in gall bladder volume, the change in weight on the balance also reflected the amount of fluid per time unit that left or entered the perfusion system and hence the net fluid transport in the gall bladder. By comparing the values estimated by these different methods, changes in gall bladder volume can be estimated. The secretion rate of hepatic bile was continuously registered by a cannula inserted in the common bile duct and connected to a drop recorder unit.

\section{SOLUTIONS AND DRUGS}

The gall bladder was perfused with an electrolyte solution (mmol/l: Na $135 ; \mathrm{K}^{+} 5 ; \mathrm{Cl}^{-} 105$; and $\mathrm{HCO}_{3}$ 35). ${ }^{14} \mathrm{C}$-labelled PEG (molecular weight approximately 4.000) was added at an amount of 74 $\mathrm{KBq} / 100 \mathrm{ml}(2 \mu \mathrm{Ci} / 100 \mathrm{ml})$ perfusate.

\section{HORMONES}

The contraceptive drugs used were etinylestradiol 10 $\mu \mathrm{g} / \mathrm{d}$ (Linoral ${ }^{\mathrm{R}}$, Organon, Holland) and levonorgestrel $30 \mu \mathrm{g} / \mathrm{d}$ (Follistrel $^{\mathrm{R}}$, Kabi Vitrum, Sweden) given daily with the morning meal. In the acute experiments etinyloestradiol (Schering AG) was given iv as a bolus injection at a dose of $10 \mu \mathrm{g} / \mathrm{kg}$, Noretisteron (Schering AG) at a dose of $60 \mu \mathrm{g} / \mathrm{kg}$ and prolactin (NIH-P-Bl-bovine, endocrinology study section NIH, Bethesda, USA) $2.5 \mathrm{mg} / \mathrm{kg}$.

\section{STATISTICAL METHODS}

Statistical significance was tested with Wilcoxon's non-parametric tests and Student's $t$ test the highest $p$ value is given.

\section{Results}

\section{PREGNANT ANIMALS}

Nine pregnant cats were studied. The normal gestation period for cats is eight weeks. The animals in the present study were examined five to eight weeks after the conception. The average body weight for these animals were then $4 \cdot 4 \pm 0 \cdot 2 \mathrm{~kg}$. The control group consisted of six female cats of a comparable age and size with an average body weight of $3 \cdot 8 \pm 0 \cdot 1 \mathrm{~kg}$. The net water absorption from the gall bladder lumen was measured in nine pregnant animals and six controls with two correlated methods (Figure). It was found that as measured with both the PEG method and the volume method there was a significantly enhanced net water absorption across the gall bladder mucosa in the pregnant animals $(\mathrm{p}<0.05)$.

The volume flow of bile from the liver during the first two hours was measured by draining the common bile duct at a pressure of $7 \mathrm{~cm} \mathrm{H}_{2} \mathrm{O}$. The average flow in the controls was $1.26 \mathrm{ml} / \mathrm{h}$ and in the pregnant animals $1.91 \mathrm{ml} / \mathrm{h}$. This difference is statistically significant (Table 1 ). 


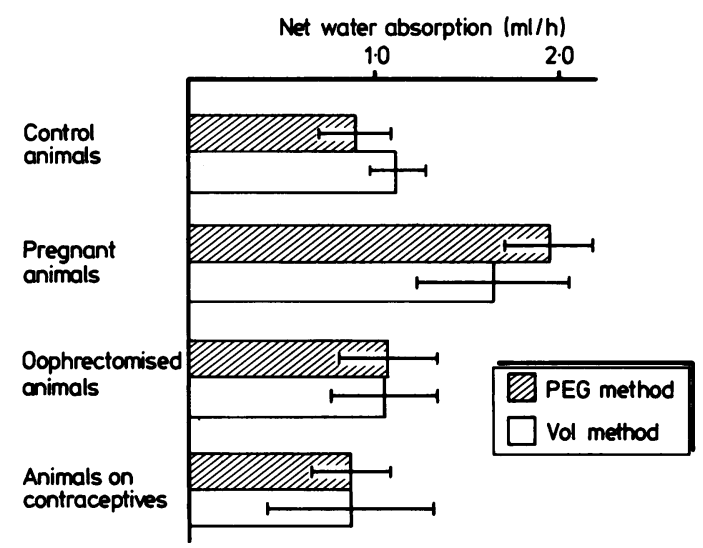

Figure Gall bladder net water absorption estimated with two separate methods in controls, pregnant animals, oophorectomised animals and animals on contraceptive steroids. The net water absorption in the pregnant animals is significantly enhanced compared with controls $(p<0.05)$.

\section{OOPHORECTOMISED ANIMALS}

Ten animals were studied for approximately three months (mean 10 weeks) after oophorectomy. From the Figure it is evident that the basal net water absorption in the gall bladder is not affected by oophorectomy. The volume outflow of bile from the liver is shown in Table 2 . It is seen that oophorectomised animals have a bile flow not significantly different from controls.

\section{INFUSION OF FEMALE SEX HORMONES IN OOPHORECTOMISED CATS}

In acute experiments the net water absorption by the gall bladder was studied before and after infusion of female sex hormones in oophorectomised cats. In four animals prolactin $(2.5 \mathrm{mg} / \mathrm{kg})$ was infused intravenously. In five animals norethistron $(60 \mu \mathrm{g} / \mathrm{kg})$ and in four animals etinyloestradiol 10 $\mu \mathrm{g} / \mathrm{kg}$ was infused intravenously. In a group of six
Table 2 Influence of pregnancy, oophorectomy and administration of contraceptives on hepatic bile secretion the first two hours after the enterohepatic circulation was broken

\begin{tabular}{llll}
\hline & $\begin{array}{l}\text { Bile flow } \\
\text { ml/hr }\end{array}$ & $\begin{array}{l}\text { Body weight } \\
\text { kg }\end{array}$ \\
\hline Control animals & $1 \cdot 26 \pm 0 \cdot 18$ & 6 & $3 \cdot 8 \pm 0 \cdot 2$ \\
Pregnant animals & $1 \cdot 91 \pm 0 \cdot 28^{*}$ & 9 & $4 \cdot 4 \pm 0 \cdot 2$ \\
Oophorectomised animals & $1 \cdot 19 \pm 0 \cdot 12$ & 7 & $3 \cdot 7 \pm 0 \cdot 1$ \\
Animals on contraceptive steroids & $2 \cdot 19 \pm 0 \cdot 32^{*}$ & 7 & $3 \cdot 8 \pm 0 \cdot 1$ \\
\hline
\end{tabular}

$\mathrm{p}<0.05,{ }^{*} \mathrm{p}<0.01$.

animals a combination of norethistron $(60 \mu \mathrm{g} / \mathrm{kg})$, and etinyloestradiol $(10 \mu \mathrm{g} / \mathrm{kg})$ was given. It can be seen that neither hormone did significantly change the net water absorption by the gall bladder.

Fasting bile flow was not markedly affected by any of the hormones (Table 2).

\section{ANIMALS TREATED WITH CONTRACEPTIVE STEROIDS}

Six animals were treated for three months $(89 \pm 9$ days) with peroral etinyloestradiol $(2.5 \mu \mathrm{g} / \mathrm{kg} /$ day $)$ and levonorgestrel $(12.5 \mu \mathrm{g} / \mathrm{kg} /$ day $)$. From the Figure it is evident that the basal net water absorption in the gall bladder is not affected by treatment with contraceptive steroids. In Table 2 it can be seen that the animals treated with contraceptives had a significantly higher bile flow than the controls $(\mathrm{p}<0 \cdot 01)$.

\section{Discussion}

In the present study it was found that the absorptive capacity of the gall bladder is enhanced in late pregnancy but is not affected by oophorectomy or administration of contraceptive steroids. The volume output of bile from the liver after fasting 24 hours is increased in pregnant animals and animals treated for three months with oral contraceptives.

Table 1 Effect of infusion of female sex hormones on gall bladder concentrating function and volume bile flow from the liver in oophorectomised cats

\begin{tabular}{|c|c|c|c|}
\hline & & Basal & Infusion \\
\hline Prolactin $2.5 \mathrm{mg} / \mathrm{kg}$ & $\begin{array}{l}\text { Net water absorption } \\
\text { Bile flow }\end{array}$ & $\begin{array}{l}1.46 \pm 0.10 \\
0.63 \pm 0.16\end{array}$ & $\begin{array}{l}1.43 \pm 0.18(n=4) \\
0.49 \pm 0 \cdot 13(n=4)\end{array}$ \\
\hline Noretisteron $60 \mu \mathrm{g} / \mathrm{kg}$ & $\begin{array}{l}\text { Net water absorption } \\
\text { Bile flow }\end{array}$ & $\begin{array}{l}0.76 \pm 0.31 \\
0.33 \pm 0.08\end{array}$ & $\begin{array}{l}0.65 \pm 0.17(n=4) \\
0.35 \pm 0.08(n=5)\end{array}$ \\
\hline Noretisteron + Etinyloestradiol & $\begin{array}{l}\text { Net water absorption } \\
\text { Bile flow }\end{array}$ & $\begin{array}{l}0.76 \pm 0.31 \\
0.33 \pm 0.08\end{array}$ & $\begin{array}{l}0.64 \pm 0.20(n=4) \\
0.51 \pm 0.21(n=6)\end{array}$ \\
\hline Etinyloestradiol $10 \mu \mathrm{g} / \mathrm{kg}$ & $\begin{array}{l}\text { Net water absorption } \\
\text { Bile flow }\end{array}$ & $\begin{array}{l}1.09 \pm 0.56 \\
0.55 \pm 0.20\end{array}$ & $\begin{array}{l}1 \cdot 12 \pm 0.55(n=4) \\
0.61 \pm 0.24(n=4)\end{array}$ \\
\hline
\end{tabular}


Administration of oestrogen, progesterone or prolactin in acute experiments did not influence neither net water absorption in the gall bladder nor hepatic bile flow.

It is earlier demonstrated that the fasting volume of the gall bladder is increased around two times in late pregnancy. ${ }^{10}$ One explanation suggested to explain this is an impaired water absorption across the gall bladder mucosa with retention of a large volume of non-concentrated bile in the gall bladder. In order not to traumatise the gall bladder no attempt was made in the present study to accurately measure the fasting gall bladder volume.

It has been shown that fluid transport by the guinea pig gall bladder in vitro is inhibited by 17 -oestradiol. ${ }^{14}$ Early studies suggested that the gall bladder in pregnancy at term did not concentrate its contents. Later, however, more careful studies could not find any difference in concentrating activity by the gall bladder reflected in absolute concentrations of biliary lipids in pregnant women and controls. ${ }^{13}$ In the present study the net water absorption in the gall bladder in late pregnancy was enhanced, when perfused by a buffer solution. The reasons for this might be that the enlarged gall bladder in pregnancy is equipped with more mucosal cells or that each cell transports more electrolytes and water away from the lumen. It is interesting to note that besides the present findings an enhanced water absorption in the gall bladder is found after truncal vagotomy ${ }^{17}$ and both pregnancy and truncal vagotomy have been associated with an increased prevalence of gall stones in man.

In the present study it is shown that the concentrating function of the gall bladder is not affected by oophorectomy or administration of contraceptive steroids. This function of the gall bladder is neither influenced by iv infusion of progesterone, oestrogen, or prolactin. These results contrast with findings in vitro presented in preliminary reports. ${ }^{4} 15$ In the quoted reports oestrogen and progesterone were found to inhibit water transport across the wall of gall bladders from female guinea pigs in vitro. The finding in the present study that prolactin did not effect gall bladder fluid transport agree with those in an earlier study by Mainoya. ${ }^{18}$ This author found that prolactin enhanced fluid and sodium chloride absorption in the rat, hamster, and guinea pig jejunum but did not affect fluid and sodium chloride absorption by the guinea pig gall bladder.

The volume output of bile from the liver in the present study was increased in pregnant animals and animals treated with contraceptive steroids. Intravenous administration of female sex hormones did not have any short term effects on bile secretion by the liver in oophorectomised animals. These results should be compared with the findings in Rhesus monkeys and rats. Lynn and coworkers ${ }^{19}$ found a reduced bile flow and bile acid secretion rate in monkeys within 12 hours after starting infusion of oestriol. Later the bile flow and bile acid secretion rate were not different from control. Gumniro and coworkers $^{20}$ treated rats for five days with ethinyl estradiol and found a reduction of bile flow to $40 \%$. This reduction was mainly accounted for by a reduced bile acid independent fraction. In the present study it was found that the bile flow in cats treated for three months with contraceptive steroids was enhanced compared with control animals. It remains to be analysed which fraction of the hepatic bile secretion that is affected by pregnancy, and contraceptive steroids.

This study was supported by grants from the Swedish Medical Research Council (17X-04984) and Gothenburg Medical Society.

\section{References}

1 Nilsson S. Gallbladder disease and sex hormones. A statistical study. Acta Chir Scand 1966; 132: 275-9.

2 Friedman GD, Kannel WB, Dawbar TR. The epidemiology of gallbladder disease: observations in the Framingham study. J Chronic Dis 1966; 19: 273-92.

3 Boston Collaborative Drug Surveillance Program. Oral contraceptive and venous thromboembolic disease, surgically confirmed gallbladder disease, and breast tumours. Lancet 1973; 1: 1399-404.

4 Boston Collaborative Drug Surveillance Program. Surgically confirmed gallbladder disease, venous thromboembolism, and breast tumours in relation to postmenopausal estrogen therapy. N Engl J Med 1974; 290: 15-9.

5 Kern F, Everson GT, DeMark B, et al. Biliary lipids bile acids, and gallbladder function in the human female. J Clin Invest 1981; 68: 1229-42.

6 Down RHL, Whiting MS, Watts JM et al. Effect of synthetic oestrogens and progestagens in contraceptives on bile lipid composition. Gut 1983; 24: 253-9.

7 McSherry CH, Javitt NB, Carvalho JM et al. Cholesterol gallstones and the chemical composition of bile in baboons. Ann Surg 1971; 173: 569-77.

8 Morrissey K, Pauveliwall D, McSherry C et al. Effects of contraceptive steroids and pregnancy on bile composition and kinetics in the baboon. J Surg Res 1977; 22: 598-604.

9 Pertsemlidis D, Pauvelivalla D, Ahrens EH. Effects of clofibrate and of an estrogen-progestin combination on fasting biliary lipids and cholic and kinetics in man. Gastroenterology 1974; 66: 565-73.

10 Braverman DZ, Johnson ML, Kern F. Effects of pregnancy and contraceptive steroids on gallbladder function. $N$ Engl J Med 1980; 302: 362-4. 
11 Riegel. C, Ravdin IS, Morrison PS et al. Studies on gallbladder function XI. The compositions of gallbladder bile in pregnancy. JAMA 1935; 105: 1343-4.

12 Potter MJ. Observations of the gallbladder and bile during pregnancy at term. JAMA 1936; 106: 1070-4.

13 Large AM, Johnston CG, Katsuki T et al. Gallstones and pregnancy: the composition of gallbladder bile in the pregnant woman at term. Am J Med Sci 1960; 91: 713, 98: 720 .

14 France VM, Menton A, Reny SR et al. The effect of 17-oestradiol on fluid transport in the in vitro guinea pig gallbladder. J Physiol (Lond) 1977; 266: 67P.

15 Che Rosali BCM, France VM. Effect of 17-estradiol on progesterone induced inhibition of fluid transported by male guinea pig gallbladder in vitro. J Physiol (Lond) 1978; 278: 30P.
16 Svanvik J, Jansson R. An experimental method for studying in vivo gallbladder absorption. Gastroenterology 1977; 72: 634-8.

17 Björck S, Jansson R, Svanvik J. The concentrating function of the feline gallbladder after truncal vagotomy. Acta Chir Scand 1984; 150: 393-7.

18 Mainoya JR, Bern HA, Regan JW. Influence of ovine prolactin on transport of fluid and sodium chloride by the mammalian intestine and gallbladder. $J$ Endocrinol 1974; 63: 311-7.

19 Lynn JL, Williams L, O'Brien J et al. Effects of estrogen upon bile. Ann Surg 1973; 178: 514-21.

20 Gumniro JJ, Valdivieso VD. Studies on the mechanism of the ethynylestradiol impairment of bile flow and bile salt excretion in the rat. Gastroenterology 1971; 61: $339-44$. 